\title{
Mean annual GPP of Europe derived from its water balance
}

\author{
C. Beer, ${ }^{1}$ M. Reichstein, ${ }^{1}$ P. Ciais, ${ }^{2}$ G. D. Farquhar, ${ }^{3}$ and D. Papale ${ }^{4}$
}

Received 12 December 2006; accepted 29 January 2007; published 6 March 2007.

[1] On local scale, the eddy covariance technique is suited to estimate gross primary production (GPP). Scaling up such observations to the regional and continental level, however, remains a challenge. Here, we show that there is a surprisingly robust stoichiometric relationship between vegetation $\mathrm{CO}_{2}$ and $\mathrm{H}_{2} \mathrm{O}$ fluxes, mediated by vapor pressure deficit (VPD), across many different forest vegetation types. This relationship is used to provide a data-driven estimate of Europe's GPP from its water balance. Namely, watershed-wide evapotranspiration (ET), as derived from precipitation $(\mathrm{P})$ and river runoff $(\mathrm{R})$, is multiplied by the ratio of GPP to ET as derived from eddy covariance measurements (water-use efficiency, WUE). In doing so, GPP of Europe is estimated to range between 3.9 and $5.8 \mathrm{PgC} / \mathrm{a}$ (median $5 \mathrm{PgC} / \mathrm{a}$ ). Such GPP estimate is an important independent benchmark for large-scale ecosystem models and may be extended to global scale when relevant data becomes available. Citation: Beer, C., M. Reichstein, P. Ciais, G. D. Farquhar, and D. Papale (2007), Mean annual GPP of Europe derived from its water balance, Geophys. Res. Lett., 34, L05401, doi:10.1029/ 2006GL029006.

\section{Introduction}

[2] GPP is the major driver of the carbon sequestration by the land surface, thus a key component of the terrestrial carbon balance. Process-oriented ecosystem models, which are required to extrapolate current knowledge in space and time, estimate global GPP from leaf photosynthesis equations [Farquhar and von Caemmerer, 1982; Ball et al., 1987; Leuning, 1995], scaled up to continents and the globe. Comparison of the thus modeled GPP to an independent data-driven estimation increased the reliability of such upscaling. Although the eddy covariance technique is suited to derive annual GPP values on a local scale [Valentini et al., 2000; Reichstein et al., 2007], observations are rare on global scale. Remotely sensed light reflectance is used to estimate spatial details of GPP by applying light-use efficiency models [Ruimy et al., 1999; Running et al., 2004], and the related root mean square error to extra-tropical site observations is reported to be $\sim 300 \mathrm{~g} \mathrm{C} / \mathrm{m}^{2} / \mathrm{a}$ or $40 \%$ [Turner et al., 2006]. In addition, the combination of remote sensing and climate data in an artificial neural network

\footnotetext{
${ }^{1}$ Max-Planck-Institut für Biogeochemie, Jena, Germany.

${ }^{2}$ Laboratoire des Sciences du Climat et de l'Environnement, Commissariat à l'Energie Atomique, Gif-sur-Yvette, France.

${ }^{3}$ Research School of Biological Sciences, Australian National University, Canberra, ACT, Australia.

${ }^{4}$ Department of Forest Resources and Environment, University of Tuscia, Viterbo, Italy.
}

Copyright 2007 by the American Geophysical Union. 0094-8276/07/2006GL029006 allows for spatial and temporal interpolation of eddy covariance measurements [Papale and Valentini, 2003].

[3] Both, carbon assimilation and transpiration depend on stomatal conductance which itself is a function of VPD [Jarvis, 1976; Leuning, 1995]. Thus, the water-use efficiency $(\mathrm{WUE}=\mathrm{GPP} / \mathrm{ET})$ multiplied by VPD remains relatively constant over time and across herbaceous vegetation types [Law et al., 2002]. This functionality of plants can be utilized to derive GPP of watersheds which can be integrated to a continental number. The long-term mean water balance of a watershed $(\mathrm{ET}=\mathrm{P}-\mathrm{R})$ is known with high accuracy of $\mathrm{R}$ and more uncertain $\mathrm{P}$, and spatially representative WUE values can be robustly inferred from eddy covariance measurements. The remaining task is to scale up the ecosystem-level WUE to whole watersheds. We therefore construct an empirical model which predicts WUE by relative plant available water holding capacity of the soil (WHC) and maximum leaf area index (LAI) (section 2) to extrapolate forest WUE based on maps of soil texture, remotely sensed land cover and LAI (section 3). The region of interest is the geographical domain of Europe excluding Russia, Belarus and Ukraine.

\section{Ecosystem-Level Water Use Efficiency}

[4] Daily numbers of VPD, GPP and ET derived from half-hourly measurements of net ecosystem exchange and latent heat by the eddy covariance technique between 1996 and 2004 [Reichstein et al., 2005; Papale et al., 2006] are used to estimate the VPD-extended WUE [g C.hPa/ $/ \mathrm{kg} \mathrm{H}_{2} \mathrm{O}$ ] for each site and year,

$$
W U E_{V P D}=\sum_{n} G P P \cdot \frac{1}{n} \sum_{n} V P D \cdot\left(\sum_{n} E T\right)^{-1}
$$

where $\mathrm{n}$ denote to the number of days within a year for which observations are available. Uncertainties of flux estimates due to the $\mathrm{u}_{*}$-selection criterion, spike detection, storage correction, gap-filling, and flux-partitioning have been quantified as discussed in the above-mentioned publications. These combined uncertainties fall within the range of 13 and $92 \mathrm{~g} \mathrm{C} / \mathrm{m}^{2} / \mathrm{a}(<10 \%)$. As a quality control, this calculation is only performed for years in which daily observations are equally distributed over the growing season and for which the correlation coefficient between daily values of GPP.VPD and ET is higher than 0.85 . In addition to these automatic quality controls, measurements in Bayreuth, DE are removed by hand since they cannot be assumed as representative because of ecosystem disturbances. Precipitation days were neglected because water flux measurements are problematic under these conditions. Then, for all remaining 13 forest and 6 grass/crop sites 


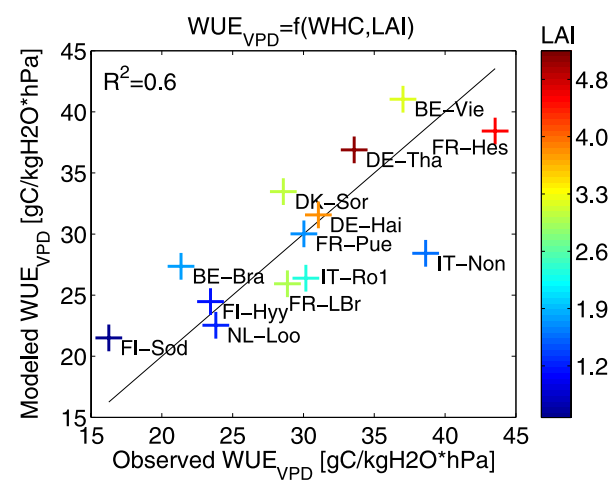

Figure 1. Validation of the $\mathrm{WUE}_{\mathrm{VPD}}$ model (equation (2)) at European forest sites. For each site, the multivariate linear regression is performed for all other sites and then applied to calculate the modeled value for this site (leave one out). The coefficient of determination related to modeled and observed $\mathrm{WUE}_{\mathrm{VPD}}, 1: 1$ line, and station identifiers are shown (see auxiliary material). Colors indicate LAI at sites.

(see auxiliary material) an average over the years is computed (hereinafter referred as WUE $\mathrm{VPD}_{\mathrm{VP}}$ ). ${ }^{1}$ Environmental gradients are responsible for a high variability of $\mathrm{WUE}_{\mathrm{VPD}}$ between forest sites (Figure 1). Therefore, we attempted to predict $W E_{V P D}$ from relatively stable environmental properties. WUE $\mathrm{VPD}_{\mathrm{VP}}$ correlates to $\mathrm{WHC}\left(\mathrm{R}^{2}=0.7, \mathrm{p}<\right.$ $0.001, \mathrm{~N}=13$; see auxiliary material), which is related to general soil quality, and the related residuals correlate with LAI $\left(\mathrm{R}^{2}=0.9, \mathrm{p}=0.07, \mathrm{~N}=4\right.$ for Fagus; $\mathrm{R}^{2}=0.7, \mathrm{p}=0.09$, $\mathrm{N}=5$ for Pinus; see auxiliary material). Thus, we regressed WUE $_{\mathrm{VPD}}$ to both properties $\left(\mathrm{R}^{2}=0.7, \mathrm{p}=0.001, \mathrm{~N}=13\right)$ (equation (2)). In equation (2) the exponential function of LAI corresponds to the fraction of absorbed sunlight in the PAR domain.

$$
W U E_{V P D}=a_{1} \cdot W H C+a_{2} \cdot\left(1-e^{-0.6 L A I}\right)+a_{3}
$$

[5] Validation of this model is performed by a 'leave-oneout cross validation' approach (Figure 1). 60\% of the variance of the thus modeled WUE $\mathrm{VPD}_{\mathrm{V}}$ can be explained by equation $(2)\left(\mathrm{R}^{2}=0.6\right)$. Without the young and high productive plantation in Nonantola, IT, $\mathrm{R}^{2}$ increased to 0.8 . Equation (2) represents more precisely spatial variability than a simple arithmetic mean and has enough predictive power to extrapolate $\mathrm{WUE}_{\mathrm{VPD}}$ of forests (section 3). WUE $_{\mathrm{VPD}}$ of young plantations might be underestimated (cf. IT-Non in Figure 1) but see uncertainty discussion in section 4 .

\section{Watershed-Wide GPP}

[6] 14 parameter sets $\left(a_{1}, a_{2}, a_{3}\right.$; see auxiliary material) estimated from multi-linear regressions (equation (2)) using all forest sites together plus removing one site at the time out of the 13 sites, respectively are combined with $\mathrm{WUE}_{\mathrm{VPD}}=$ $17.23 \pm 0.84 \mathrm{~g} \mathrm{C} \cdot \mathrm{hPa} / \mathrm{kg} \mathrm{H}_{2} \mathrm{O}$ (see auxiliary material) for

${ }^{1}$ Auxiliary materials are available in the HTML. doi:10.1029/ 2006GL029006. grassland and cropland to derive 42 European maps of $\mathrm{WUE}_{\mathrm{VPD}}(1 \mathrm{~km}$ pixel size). In doing so, we merge maps of land cover [Friedl et al., 2002; Hansen et al., 2003], LAI [Myneni et al., 2002], and soil texture [European Soil Bureau Network and the European Commission, 2004]. The application of these 14 parameter sets $\left(a_{1}, a_{2}, a_{3}\right)$ is to demonstrate the high robustness of equation (2) on which relies the upscaling of forest WUE $E_{V P D}$. After aggregation to a $0.1^{\circ}$ cell size these estimates are divided by day-time VPD averaged over the growing season to derive a European map of WUE in $\mathrm{g} \mathrm{C} / \mathrm{kg} \mathrm{H}_{2} \mathrm{O}$ (Figure 2). As a surrogate for a ETweighted average, an average spatially weighted by annual $\mathrm{P}$ is applied then to scale WUE to whole watersheds. For uncertainty analysis, we apply 6 different sets of climate data. P came from the Climate Research Unit of the University of East Anglia, UK (CRU) [New et al., 2002], the Global Precipitation and Climate Project (GPCP) [Adler et al., 2003], and the regional climate model (REMO) [Jacob and Podzun, 1997]. From the latter resource we also use VPD in addition to the NASA Data Assimilation
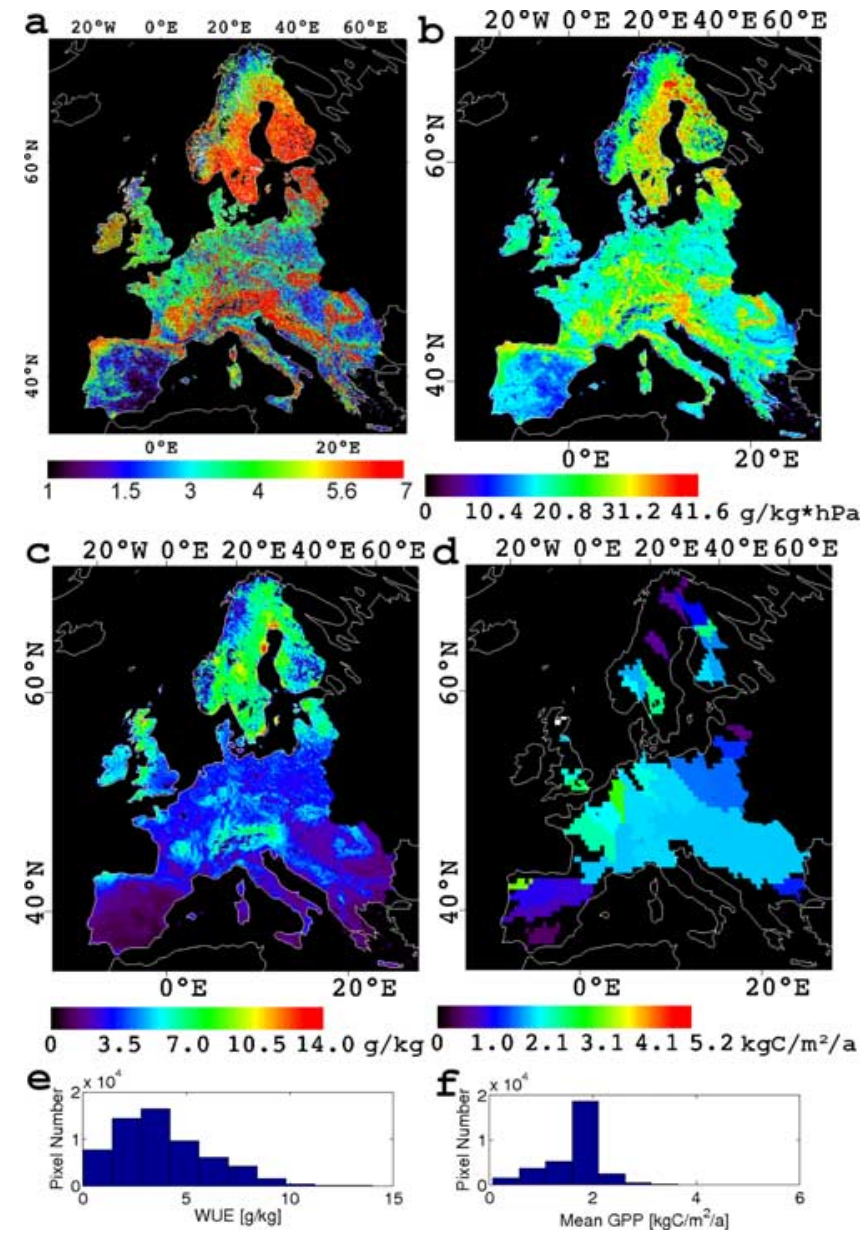

Figure 2. Spatial details of (a) MODIS maximum LAI, (b) WUE $\mathrm{VPD}_{\mathrm{VP}}$, (c) WUE, and (d) mean GPP of watersheds. Day-time VPD averaged over the growing season between 2000 and 2003 by DAO is used to calculate Figure 1c from Figure $1 \mathrm{~b}$. In addition, precipitation provided by CRU climatology is used to derive Figure 1d from Figure 1c. $(e-f)$ Histograms of values in Figures $1 \mathrm{c}$ and $1 d$. 
Table 1. Net Primary Production (NPP) and GPP of Europe Excluding Russia, Belarus and Ukraine ${ }^{\mathrm{a}}$

\begin{tabular}{lccc}
\hline & Area, Mha & NPP, PgC/a & GPP, PgC/a \\
\hline Land use type & & & \\
Forest & $143^{\mathrm{b}}$ & $0.7^{\mathrm{b}}$ & $1.2-4.8(1.4)^{\mathrm{g}}$ \\
Cropland $^{\mathrm{c}}$ & $44^{\mathrm{d}}$ & $0.4^{\mathrm{e}}$ & 0.7 \\
Grassland & $138^{\mathrm{f}}$ & $1^{\mathrm{f}}$ & 1.7 \\
Total & 325 & 2.1 & $3.6-4.2(3.8)^{\mathrm{g}}$ \\
This study & 280 & - & $3.9-5.8$ \\
\hline
\end{tabular}

${ }^{a}$ Except for results by this study, GPP is calculated by applying NPP/GPP ratios of $0.4-0.6$ (forest), 0.55 (cropland), and 0.6 (grassland) [Lloyd and Farquhar, 1994; S. Luyssaert et al., Global patterns in forest $\mathrm{CO}_{2}$ balance An analysis based on a new global database, submitted to Global Change Biology, 2007].

${ }^{\mathrm{b}}$ Nabuurs et al. [2003].

${ }^{\mathrm{C}}$ Arable land minus pasture.

${ }^{\mathrm{d}}$ Food and Agriculture Organisation [2004].

${ }^{\mathrm{e}}$ Assuming $900 \mathrm{~g} \mathrm{C} / \mathrm{m}^{2} / \mathrm{a}$ [de Noblet-Ducoudré et al., 2004].

${ }^{\mathrm{f}}$ Vuichard et al. [2007].

${ }^{\mathrm{g}}$ Assuming NPP/GPP $=0.5$ for forest.

Office (DAO) [Data Assimilation Office, 2002]. Spatial resolution are $0.1^{\circ}$ for both CRU and GPCP data, and $0.25^{\circ}$ for REMO results. Time periods of averaging are 2000-2003 (DAO and GPCP), 1961-1990 (CRU), and 1961-2003 (REMO). Long-term mean annual river discharges were provided by The Global Runoff Data Centre, D-56002 Koblenz, Germany (available at http://grdc.bafg.de/). For each watershed, the product of annual $\mathrm{ET}=\mathrm{P}-\mathrm{R}$ and upscaled WUE leads to mean annual GPP. Tables of GPP, and mean GPP and WUE of all watersheds can be found in the auxiliary material. The 252 maps of watershed-wide GPP integrate to GPP of Europe between 3.9 and $5.8 \mathrm{PgC} / \mathrm{a}$ (median $5 \mathrm{PgC} / \mathrm{a}$ ). Figure $2 \mathrm{~d}$ shows one example of mean GPP of watersheds with the density of their distribution in Figure 2f. Mean GPP ranges mostly between 0.5 and $2.5 \mathrm{~kg} \mathrm{C} / \mathrm{m}^{2} / \mathrm{a}$ in accordance with observations in forests [Reichstein et al., 2007].

\section{Discussion}

[7] This study aims at estimating GPP of Europe by exploiting the water balance and WUE of catchment basins. Uncertainties are related to (1) the observation of annual GPP and ET by the eddy covariance technique, (2) the extrapolation of resulting WUE to whole watersheds, and (3) the estimate of the mean annual water balance of the river basins. To account for uncertainties related to points 1 and 2, we applied the full range of parameter sets of equation (2) derived from regressions by removing one site at the time out of the 13 sites, respectively. In addition, the standard error of WUE $\mathrm{VPD}_{\mathrm{VP}}$ of grassland and cropland was propagated, i.e., uncertainties of GPP, ET, LAI, and WHC values are assumed to be explained by the variance of WUE $_{\mathrm{VPD}}$ between sites. Potential overall biases by the eddy covariance technique, e.g., $0-20 \%$ underestimation of ET [Wilson et al., 2002] or $0-10 \%$ overestimation of GPP (advection) would linearly translate into respective overestimation or underestimation of WUE, thus GPP. Uncertainties due to the maps of soil texture, land cover and LAI are not taken into account. They are assumed to be low compared to point 3 since accuracy of remotely sensed forest cover is high (available at http://www-modis.bu.edu/ landcover/userguidelc/consistent.htm) and sensitivity of LAI in equation (2) small. In addition, land cover and LAI products should be derived consistently by using the same light reflectance data. For soil texture data, we do not know any better map with similar resolution. To account for uncertainty introduced by point 3 , WUE $E_{\mathrm{VPD}}$ maps are applied to 6 different sets of climate data. Additional uncertainty due to anthropogenic water usage should be clarified in future studies.

[8] This study demonstrates the capability of exploiting the linkage between water and carbon cycles for the estimation of GPP on global scale which is not observable per se but highly required as an independent benchmark for large-scale ecosystem models which are part of GCMs. The thus estimated GPP of Europe is in the range of combined results by inventory and models (Table 1). Estimated numbers per area, however, are slightly higher. There are productive coastal regions which are not taken into account (Figure 2d) due to lacking discharge data, e.g., Ireland, Northern Spain, and in Sweden and Italy. A sixfold area of Ireland (45 Mha, cf. Table 1) with GPP of $1500 \mathrm{~g} \mathrm{C} / \mathrm{m}^{2} / \mathrm{a}$ translated into a GPP underestimation of $0.63 \mathrm{PgC} / \mathrm{a}$ or $13 \%$. In general, the presented method allowed for global and inter-annual resolved GPP estimates, too. The thus datadriven anomalies could be compared to anomalies derived from bottom-up ecosystem models or top-down atmospheric inversions allowing for deeper process understanding.

[9] Acknowledgments. Collection of NEE and latent heat data was funded by the European Commission's Integrated Project CarboEurope. Many thanks to M. Aubinet $(2 x)$, Z. Barkza, C. Bernhofer $(2 x)$, N. Buchmann, K. Pilegaard, A. Granier, G. Kiely, A. Knohl, W. Kutsch, T. Laurila, D. Lousteau, E. Moors, Z. Nagy, S. Rambal, E.-D. Schulze, H. Soegaard, Z. Tuba, R. Valentini, and T. Vesala. Their eddy covariance measurements are the basis for this work. We thank S. Luyssaert for indications about the NPP/GPP ratio of forests, and C. Rödenbeck and all members of the CarboEurope workshop in Amsterdam, 15-16 June 2006 for valuable comments. C. B. and M. R. are grateful to the Max-Planck Society for supporting the Biogeochemical Model-Data-Integration Group as 'Independent Junior Research Group'.

\section{References}

Adler, R., et al. (2003), The version 2 Global Precipitation Climatology Project (GPCP) monthly precipitation analysis (1979-present), J. Hydrometeorol., 4, 1147-1167.

Ball, J. T., I. E. Woodrow, and J. A. Berry (1987), A model predicting stomatal conductance and its contribution to the control of photosynthesis under different environmental conditions, in Progress in Photosynthesis Research, vol. 4, edited by J. Biggins, pp. 221-224, Springer, New York.

Data Assimilation Office (2002), Algorithm theoretical basis document, technical report, NASA, Greenbelt, Md.

de Noblet-Ducoudré, N., S. Gervois, P. Ciais, N. Viovy, N. Brisson, B. Seguin, and A. Perrier (2004), Coupling the soil-vegetationatmosphere-transfer scheme ORCHIDEE to the agronomy model STICS to study the influence of croplands on the European carbon and water budgets, Agronomie, 24, 397-407.

European Soil Bureau Network and the European Commission (2004), European Soil Database version 2.0 [CD-ROM], Ispra, Italy.

Farquhar, G. D., and S. von Caemmerer (1982), Modelling of photosynthetic response to environmental conditions, in Physiological Plant Ecology II: Water Relations and Carbon Assimilation, edited by P. S. Nobel, C. B. Osmond, and H. Ziegler, pp. 549-587, Springer, New York.

Food and Agriculture Organisation (2004), FAO Statistical Yearbook, vol. 1, Rome.

Friedl, M., et al. (2002), Global land cover mapping from MODIS: Algorithms and early results, Clim. Res., 83(1-2), 287-302.

Hansen, M., R. DeFries, J. Townshend, M. Carroll, C. Dimiceli, and R. Sohlberg (2003), Global percent tree cover at a spatial resolution of 500 meters: First results of the MODIS vegetation continuous fields algorithm, Earth Interact., 7, 1-15. 
Jacob, D., and R. Podzun (1997), Sensitivity studies with the regional climate model REMO, Meteorol. Atmos. Phys., 63, 119-129.

Jarvis, P. G. (1976), The interpretation of the variations in leaf water potential and stomatal conductance found in canopies in the field, Philos. Trans. R. Soc. London, Ser. B, 273(927), 593-610.

Law, B., et al. (2002), Environmental controls over carbon dioxide and water vapor exchange of terrestrial vegetation, Agric. For. Meteorol., 113, 97-120.

Leuning, R. (1995), A critical appraisal of a combined stomatal-photosynthesis model for $\mathrm{C}_{3}$ plants, Plant Cell Environ., 18(4), 339-355.

Lloyd, J., and G. D. Farquhar (1994), ${ }^{13} \mathrm{C}$ discrimination during $\mathrm{CO}_{2}$ assimilation by the terrestrial biosphere, Oecologia, 99, 201-215.

Myneni, R., et al. (2002), Global products of vegetation leaf area and fraction absorbed PAR from year one of MODIS data, Clim. Res., $83(1-2), 214-231$.

Nabuurs, G.-J., M.-J. Schelhaas, G. M. J. Mohren, and C. B. Field (2003), Temporal evolution of the European forest sector carbon sink from 1950 to 1999, Global Change Biol., 9, 152-160.

New, M., D. Lister, M. Hulme, and I. Makin (2002), A high-resolution data set of surface climate over global land areas, Clim. Res., 21(1), 1-25.

Papale, D., and R. Valentini (2003), A new assessment of European forests carbon exchanges by eddy fluxes and arificial neural network spatialization, Global Change Biol., 9, 525-535.

Papale, D., et al. (2006), Towards a standardized processing of net ecosystem exchange measured with eddy covariance technique: Algorithms and uncertainty estimation, Biogeosciences, 3, 1-13.

Reichstein, M., et al. (2005), On the separation of net ecosystem exchange into assimilation and ecosystem respiration: review and improved algorithm, Global Change Biol., 11, 1424-1439.

Reichstein, M., et al. (2007), Determinants of terrestrial ecosystem carbon balance inferred from European eddy covariance flux sites, Geophys. Res. Lett., 34, L01402, doi:10.1029/2006GL027880.
Ruimy, A., L. Kergoat, and A. Bondeau (1999), Comparing global models of terrestrial net primary productivity (NPP): Analysis of differences in light absorption and light-use efficiency, Global Change Biol., 5, suppl. $1,56-64$.

Running, S., R. Nemani, F. Heinsch, M. Zhao, M. Reeves, and H. Hashimoto (2004), A continuous satellite-derived measure of global terrestrial primary production, BioScience, 54(6), 547-560.

Turner, D., et al. (2006), Evaluation of MODIS NPP and GPP products across multiple biomes, Remote Sens. Environ., 102(3-4), 282-292.

Valentini, R., et al. (2000), Respiration as the main determinant of carbon balance in european forests, Nature, 404(6780), 861-865.

Vuichard, N., P. Ciais, N. Viovy, P. Calanca, and J.-F. Soussana (2007), Estimating the greenhouse gas fluxes of European grasslands with a process based model: 2. Simulations at the continental level, Global Biogeochem. Cycles, 21, GB1005, doi:10.1029/2005GB002612.

Wilson, K., et al. (2002), Energy balance closure at FLUXNET sites, Agric. For. Meteorol., 113, 223-243.

C. Beer and M. Reichstein, Max Planck Institute for Biogeochemistry, P.O. Box 1001 64, D-07701 Jena, Germany. (cbeer@bgc-jena.mpg.de)

P. Ciais, Laboratoire des Sciences du Climat et de L'Environnement, Commissariat à l'Energie Atomique, Orme des Merisiers, F-91191 Gif-surYvette, France.

G. D. Farquhar, Research School of Biological Sciences, Australian National University, GPO Box 475, Canberra, ACT 2601, Australia.

D. Papale, Department of Forest Resources and Environment, University of Tuscia, Via S. Camillo de Lellis s.n.c., I-01100 Viterbo, Italy. 